\title{
SPANXC wt Allele
}

National Cancer Institute

\section{Source}

National Cancer Institute. SPANXC wt Allele. NCI Thesaurus. Code C92969.

Human SPANXC wild-type allele is located in the vicinity of Xq27.1 and is approximately 1 $\mathrm{kb}$ in length. This allele, which encodes sperm protein associated with the nucleus on the $\mathrm{X}$ chromosome $\mathrm{C}$ protein, may play a role in the formation of spermatids. 